\section{Case of Septicaemia due to Yersinia enterocolitica}

\author{
B. CHESSUM, J. D. FRENGLEY, D. G. FLECK, \\ N. S. MAIR
}

British Medical fournal, 1971, 3, 466

There are few reports of septicaemia due to Yersinia enterocolitica. In a recent review Mollaret and his associates (1971) could find records of only some 19 authenticated cases between 1949 and 1970. So far as we know the case of septicaemia described below is the first human infection with $Y$. enterocolitica to be reported in Britain.

\section{Case Report}

The patient, a 69-year-old retired professional man, generally in good health, became unwell on 15 June 1970 with fever and general malaise three days after returning from a Mediterranean cruise. He had one loose stool on the day of return. On the second day he developed mild tenderness in the left calf. On the following day he was given ampicillin $500 \mathrm{mg}$ six-hourly by mouth after stool and blood samples had been taken. There was little change in the ensuing two days and he was admitted to hospital on 20 June with the provisional diagnosis of enteric fever. There was nothing of note in his past history except for a moderate consumption of alcohol.

Examination showed a moderately ill man with a temperature of $38.5^{\circ} \mathrm{C}$ and a pulse rate of 90 . His liver edge was $2 \mathrm{~cm}$ below the right costal margin and smooth. There was slight tenderness of a superficial vein in the left calf. No other abnormalities were found. On admission ampicillin was stopped. Forty-eight hours after admission with no treatment his temperature became normal. When seen as an outpatient three weeks later he was well with no symptoms and no abnormal findings.

Investigations. -18 June: $\mathrm{Hb} 15.5 \mathrm{~g} / 100 \mathrm{ml}$; W.B.C. $8,000 / \mathrm{mm}^{3}$; E.S.R. $26 \mathrm{~mm} / \mathrm{hr}$ (Westergren). 22 June: $\mathrm{Hb} 16.1 \mathrm{~g} / 100 \mathrm{ml}$; W.B.C. $9,000 / \mathrm{mm}^{3}$ (polymorphs $71 \%$, lymphocytes $20 \%$, monocytes $8 \%$, eosinophils $1 \%$ ); blood film showed pronounced rouleaux formation and leucocytes a left shift, with toxic granulation; E.S.R. had increased to $86 \mathrm{~mm} / \mathrm{hr}$. 25 June: liver function tests showed serum bilirubin $0.2 \mathrm{mg} / 100 \mathrm{ml}$, alkaline phosphatase $125 \mathrm{IU} /$ litre, serum aspartate aminotransferase (SGOT) $13 \mathrm{IU} /$ litre, and serum alamine aminotransferase (SGPT) 25 IU/litre; fasting blood sugar $110 \mathrm{mg} / 100 \mathrm{ml}$. 13 July: serum bilirubin $0.2 \mathrm{mg} / 100 \mathrm{ml}$; alkaline phosphatase $176 \mathrm{IU} /$ litre; SGOT 9 IU/litre; SGPT $10 \mathrm{IU} /$ litre; thymol turbidity 2.3 units. Agglutination tests for salmonella and Brucella abortus on 18 and 22 June were negative. Faeces cultures were negative for salmonella and shigella. A Gram-negative coccobacillus was isolated from a blood culture taken on the day after admission. Serum taken on 22 June agglutinated the patient's strain and a stock strain of $Y$. enterocolitica type 3 (Winblad, 1967) to a titre of $1 / 1,280$ and $1 / 2,560$ respectively. Three weeks later titres had fallen to $1 / 320$ and $1 / 640$ respectively.

St. George's Hospital, London S.W.17

B. CHESSUM, F.I.M.L.T., Head Technician, Public Health Laboratory D. G. FLECK, M.D., M.R.C.PATH., Director, Public Health Laboratory

J. D. FRENGLEY, M.B., M.R.C.P., Microbial Discases Unit

Public Health Laboratory, Groby Road Hospital, Leicester LE3 9QE N. S. MAIR, F.R.C.PATH., DIP.BACT., Director

\section{BACTERIOLOGY}

The organisms isolated from the blood culture were small, oval, Gram-negative rods, motile at $22^{\circ} \mathrm{C}$ but not at $37^{\circ} \mathrm{C}$. Growth was good on nutrient agar, horse blood agar, and MacConkey agar at $37^{\circ}, 30^{\circ}$, and $22^{\circ} \mathrm{C}$. Growth on blood agar did not produce haemolysis. On deoxycholate-citrate agar growth was scarcely visible after 18 hours at $37^{\circ} \mathrm{C}$ but good at 48 hours. Growth was uniformly turbid in nutrient broth at $37^{\circ} \mathrm{C}$.

Biochemical Reactions.-Acid without gas formed after 18 hours at $37^{\circ} \mathrm{C}$ in glucose, mannitol, sucrose, sorbitol, arabinose, trehalose, and glycerol; lactose, maltose, salicin, dulcitol, inositol, adonitol, raffinose, rhamnose, xylose, melibiose, and inulin not fermented after 14 days; fermentation of glucose in Hugh and Liefson's medium; methyl-red positive at room temperature and $37^{\circ} \mathrm{C}$, Voges-Proskauer positive at room temperature and negative at $37^{\circ} \mathrm{C}$; no growth in Koser's citrate or Møller's KCN broth; production of decarboxylase for orinthine but not for arginine of lysine; indole and H.S not produced; gelatin not liquefied; oxidase negative; catalase, urease, and $\beta$-galactosidase produced; nitrates reduced; esculin not hydrolysed. With the use of sensitivity discs the culture was sensitive to sulphamethoxazole/trimethoprim, cephalosporin, streptomycin, tetracycline, chloramphenicol, sulphonamide, carbenicillin, and gentamicin but resistant to ampicillin.

Serological tests showed that the strain belonged to $Y$. enterocolitica type 3 according to Winblad's antigenic scheme.

Mice, guinea-pigs, and hamsters survived intraperitoneal and intramuscular inoculation with up to $2 \mathrm{ml}$ of an overnight broth culture without showing signs of illness. Necropsy in these animals eight weeks later failed to show lesions either at the sites of inoculation or in the viscera.

\section{Comment}

Increasingly frequent isolations have been recorded in man associated with cases of enteritis, acute terminal ileitis, mesenteric lymphadenitis, and erythema nodosum (Winblad et al., 1966; Wauters et. al., 1967; Jansson et. al., 1968; Nilehn 1969). Finnish workers have claimed, on the basis of serology, to have found an association between $Y$. enterocolitica and polyarthritis (Ahvonen et al., 1969).

Most cases of septicaemia due to $Y$. enterocolitica appear to be associated with underlying disease, such as leukaemia, diabetes, or cirrhosis of the liver, or are iatrogenic in origin, occurring in patients undergoing peritoneal dialysis, intravenous perfusion, or immunosuppressive therapy (Mollaret et al., 1971). In this respect the present case was unusual in that there was little evidence of concomitant disease. The minimal rise of SGPT after 10 days of fever does not imply liver disease, and this is supported by its return to normal values three weeks later. Though Y. enterocolitica is not a common cause of septicaemia this case shows that it is not necessarily an opportunistic infection.

Requests for reprints should be sent to Dr. N. S. Mair.

\section{References}

Ahvonen, P., Sicvers, K., and Aho, K. (1969). Acta Rheumatologica Scandinavica, 15, 232.

Jansson, E., Wallgren, G. R., and Ahvonen, P. (1968). Acta Paediatrica Scandinavica, 57, 448 .

Mollaret, H. H., et al. (1971). Presse Médicale, 79, 345.

Nilehn, B. (1969). Acta Pathologica et Microbiologica Scandinavica, Suppl. No. 206

Wauters, G., Graux, C., and Bruynoghe, G. (1967). Presse Médicale, 75, 1965

Winblad, S. (1967). Acta Pathologica et Microbiologica Scandinavica. Suppl. No. 187, p. 115 .

Winblad, S., Niléhñ, B., and Sternby, N. H., (1966). British Medical Fournal, 2, 1363 . 